\title{
Students' Decision in Choosing Universities by International Rankings
}

\author{
Roxana - Adriana PUIU (MECHNO), Gabriel PETREA, Diana SCURTU, Maria \\ - Nicoleta CRISTEA and Remus - Andrei DOBRINOIU
}

University POLITEHNICA of Bucharest, Bucharest, Romania

Correspondence should be addressed to: Roxana - Adriana PUIU; mechnoroxana@yahoo.com

Received date: 18 November 2020; Accepted date: 10 February 2021; Published date: 6 June 2021

Academic Editor: Mioara Duca

Copyright (C) 2021. Roxana - Adriana PUIU (MECHNO), Gabriel PETREA, Diana SCURTU, Maria Nicoleta CRISTEA and Remus - Andrei DOBRINOIU. Distributed under Creative Commons Attribution 4.0 International CC-BY 4.0

\begin{abstract}
All over the world, the rankings play an important role for any potential student who chooses his own university. Given that, more and more young people are interested in investing in their education, wanting to pursue a rigorous specialization. It is of great importance to consider how students choose which university they will join. Thus, not only students use international rankings, but universities are also showing a greater dependence on them as well. Thereby, in recent years, there has been an increase in the interest of higher education institutions around the world to be classified in international rankings. This paper aims to identify the impact that international rankings have on students' decisions to choose a university. At the same time, it aims to identify the ways in which universities try to differentiate themselves in order to be as attractive as possible among students. Withal, the authors of this paper will detail the factors that influence the choice made by students. Finally, the paper will focus on the future perspective of performing a mathematical modelling to identify the share of influence of these factors on students' decisions for choosing the university.
\end{abstract}

Keywords: Ranking, Higher Education, Research, Students.

\section{Introduction}

Worldwide, the interest in university rankings emerged in 2013, with the publication of the first editions of ARWU (Academic Ranking of World Universities) by Prof. Nian Cai Liu (Shanghai Jiao Tong

Cite this Article as: Roxana - Adriana PUIU (MECHNO), Gabriel PETREA, Diana SCURTU, Maria - Nicoleta CRISTEA and Remus - Andrei DOBRINOIU" Students' Decision in Choosing Universities by International Rankings", Journal of e-Learning and Higher Education, Vol. 2021 (2021), Article ID 361886,

DOI: $10.5171 / 2021.361886$ 
University). This ranking is the result of the policy initiated by Jian Zemin in 1998, with the aim of propelling China among the major research players globally, by creating "world class universities" comparable to the best Western universities. The larger interest for this ranking has led to new global rankings, as well as the initiation in some countries (France, South Korea, Taiwan, India, etc.) of funding programs to stimulate the positioning of some universities among those of "world class" type.

A consequence of the growing interest in university rankings at a global level is also given by the attention manifested at government level, and by the debate regarding the objectives which must be considered by the education and research department policies. Basically, the universities want to be present in as many international rankings as possible, wishing to be more visible among stakeholders, and among the public, in general. Two visions can be identified here: "world class universities" or "word class systems". Globally, it is noted that some negative effects are generated by the concentration in some countries on the first option policies (the decline for the interest of academics in teaching, the encouragement of layering in university systems generating social inequalities, the lower interest for social sciences and humanities, etc.). Simon Marginson, from Oxford University, notes that the transition to the second plan of teaching - learning process, leads to an increase in the mass of those who form a low-quality academic system. For this reason, the UK government has created a "teaching excellence framework" which aims to improve the quality of education. The stratification of universities, with some being accepted in rankings as "world class universities", is stimulated by competition in the allocation of research funds.

In Romania, as of mid-2017, the ARUT Consortium (Romanian Alliance of Technical Universities) has been established, which aims at the following aspects:
- Most rankings monitor a relatively small number of universities. In the case of Romania, only 10 out of approximately 100 universities are present in international rankings. Mostly, these rankings take into account the size of the university and the quality of education.

- Critics of ranking systems argue, both in terms of content (onedimensionality, negligence of input-output structures of universities, etc.), and in terms of methodology (statistical robustness, elitism, dependence on the size of the institution, an attempt to impose a certain view of the role of universities, etc.).

- The allocation of resources based on these rankings is a questionable decision, and the priorities of the development are not automatically resolved by such a policy.

\section{International Rankings}

Currently, there are more than 20 international rankings worldwide. To have a comprehensive picture of a university's academic performance, a complex analysis of the most relevant rankings is needed. Below, a list of the 11 international rankings that will be analyzed, is presented:

1. ARWU (Academic Ranking of World Universities http://www.shanghairanking.com );

2. NTU Ranking (National Taiwan University Ranking http://nturanking.lis.ntu.edu.tw);

3. THE (Times Higher Education World University Rankings https://www.timeshighereducatio n.com/, UK);

4. CWTS Leiden Ranking (www.leidenranking.com, Holland, CWTS also involved in UMultirank);

5. QS World University Rankings (https://www.topuniversities.com Luniversity-rankings, UK);

6. URAP (University Ranking by Academic Performance, 
http://www.urapcenter.org/2018 L Turkey);

7. SIR (SCImago Institutions Rankings,

https://www.scimagoir.com/ Spain);

8. CWUR (Center for World University Rankings, https://cwur.org/, Emirates);

9. US News Best Global University Ranking (https://www.usnews.com/educat ion/best-global-universities);

10. U-MULTIRANK (https://www.umultirank.org/, UE);

11. Google Scholar Citations (https://scholar.google.com/).
The indicators used to make the rankings and their weighting in the total score differ from one ranking to another. Overall, they can be grouped into 4 fields of analysis: Learning environment, Quality of research, Transfer of knowledge and international orientation (including societal impact). Another important aspect to consider, regarding the assessment of the relevance of rankings, is related to the weight of indicators that depend on the size of the university, relative to those that are oriented at the performances per capita (per total academic staff, per number of students, etc.).

Table 1 presents the main performance indicators and their weighting over the fields of analysis, for the 11 rankings mentioned above.

Table 1: Performance indicators

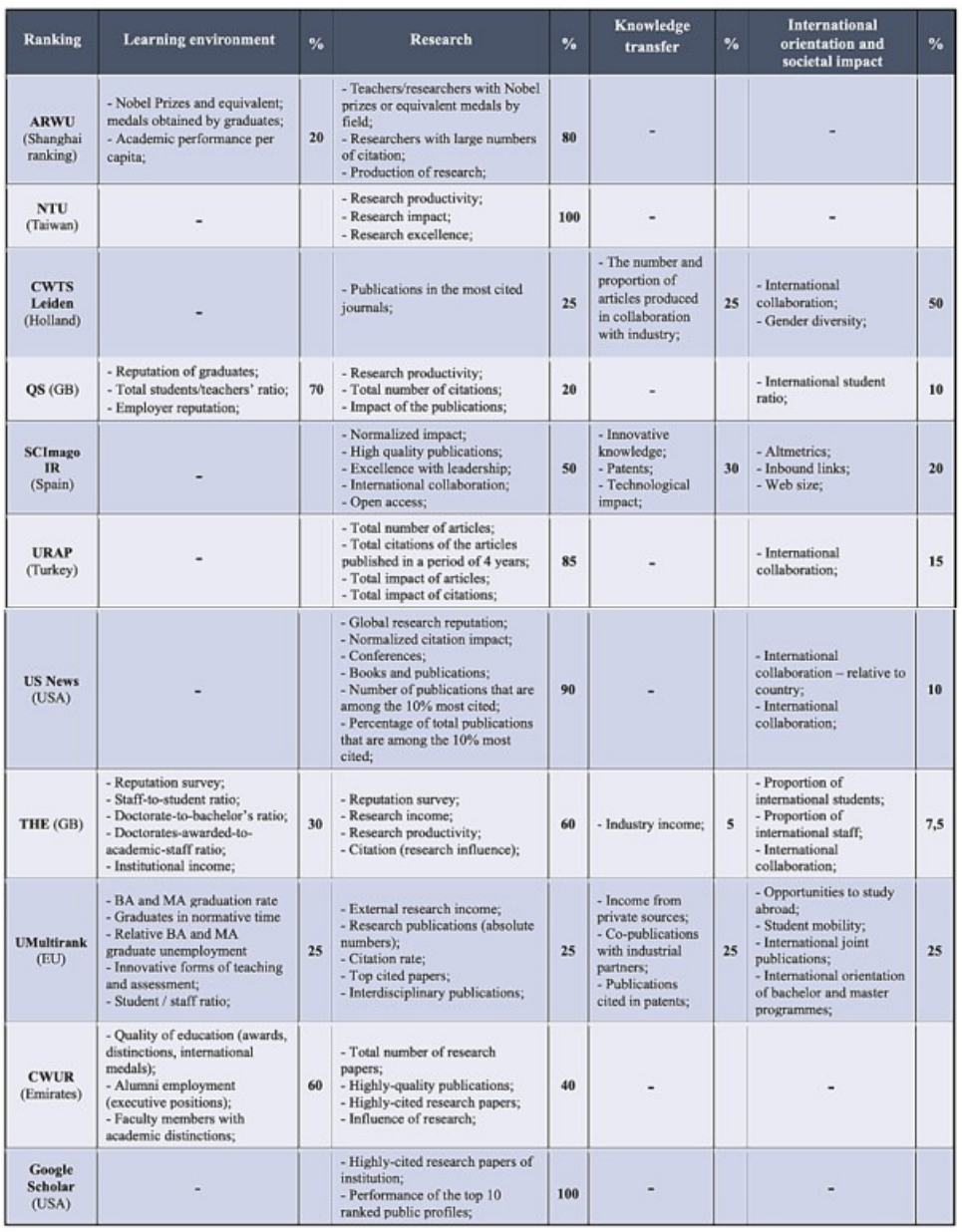

Roxana - Adriana PUIU (MECHNO), Gabriel PETREA, Diana SCURTU, Maria - Nicoleta CRISTEA and Remus - Andrei DOBRINOIU" Students, Journal of e-Learning and Higher Education, DOI: 10.5171/2021.361886 
in fact, there are two important questions: why do we need these rankings? Why do most universities want to join as many such rankings as possible and get the best positions in them?

The answer is a very simple one, namely, to increase the prestige of the university. What does this mean? The prestige of the university attracts as many high school students as possible, those who are the future students at the university.

\section{What are universities doing to attract future students?}

One of the priorities of any university, in line with its objectives, is to promote the educational offer among the public, in general, to attract as many talented high school students (future students) as possible, including from abroad. The aim is to increase the prestige, visibility, and attractiveness of a higher education institution. Among the actions taken by universities to attract future students, the following can be listed:

\section{Diversification of specializations}

From the exact sciences, such as mathematics, physics and chemistry, to humanities, letters, history, sociology, etc., universities are increasingly seeking to expand their portfolio. The information is often found on university websites or on websites specifically dedicated to them.

\section{Weekly newsletters}

Another way to attract students is by making weekly newsletters. Therefore, universities communicate everything that happens within all faculties, both internally and internationally. They can include information on conferences, special events for students and high school students, admission, scientific communication sessions, special scholarships, competitions and conditions for participation, opportunities, workshops, etc.

\section{Career fairs and internships}

One of the most common ways to attract students is to organize career fairs and internships frequently. Their aim is to help students fit more easily into the labor market. Each faculty has partnerships with different companies, which offer internship programs to all those interested, but at the same time, offer them the freedom to choose from the existing offers on the market, if the specificity of the studies program is respected.

\section{Scholarships for exchange of experience}

Scholarships are found in most higher education institutions and offer students the opportunity to attend courses abroad for a certain period, like those of the university they attend in their country. Thus, they gain an international experience, deal with a different education system, and develop additional skills.

\section{Attracting foreign students}

Like students of the country who have the possibility to study abroad for a certain period, foreign students can benefit from the same opportunity in the country. In addition to the Erasmus programs, they can also choose to study fully at a university if they take training courses in the language of that country, which take place before the actual studies begin. Therefore, foreign students are helped to integrate more easily, and their participation in courses will be facilitated.

\section{The prestige of the university}

As mentioned above, one of the most important criteria for increasing the prestige of a university can be to occupy the highest position in the international rankings.

But is it enough that only the university should take certain steps to attract its future students? 
In the following section, the main factors influencing the student's decision to choose a university will be presented.

\section{How do students choose the faculty they want to join?}

In October 2020, the Romanian Centre for Urban and Regional Sociology (CURS) conducted a national opinion poll, in which it tried to identify the main decisionmakers in choosing a university.

The sampling of the survey was based on stakeholders from pre-university education, namely: students, high-school students, and teachers. The sample volume was 1.068 respondents. The sample type was probabilistic, multistage, and stratified. The maximum margin of error across the entire sample was $+/-3 \%$, at a
95\% confidence level. The sample was validated based on the latest data from the National Institute of Statistics (INS) and the Education and Research Ministry (MEC) from Romania.

As shown in Figure 1, regarding the question "What are the main reasons why you would choose or recommend a form of study", almost half of the respondents (42\%) mentioned that "they have heard from others/knowns". Weighted by 36\%, the following answer was "I studied/study there". "The quality", or as we call it in this article, the prestige of the institution, is the response provided by only $29 \%$ of the respondents. At the opposite side, $10 \%$ and 9\% are for the answers "good teachers" and "good students/graduates", respectively.

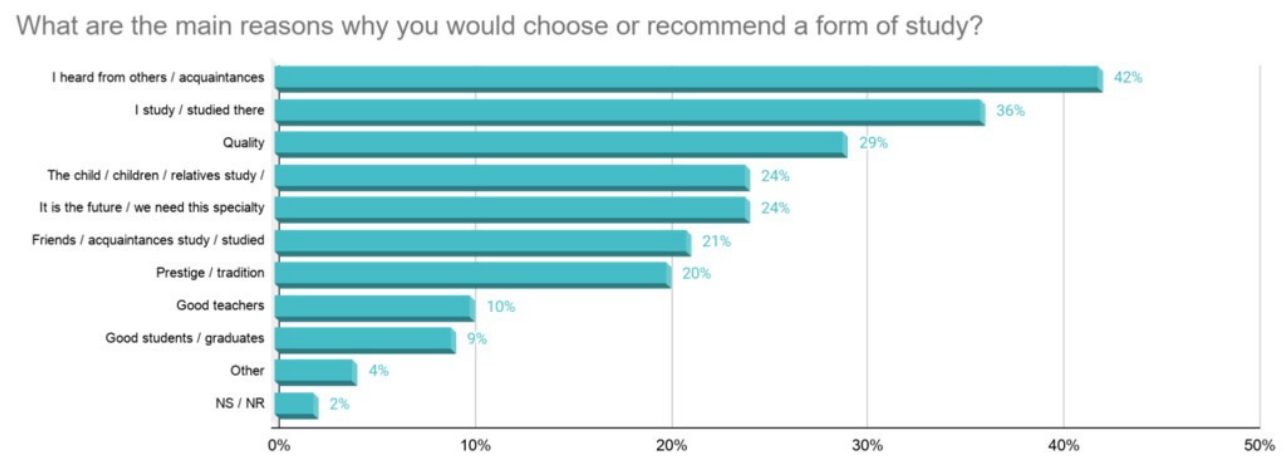

Figure 1

Another question answered by the 1,068 respondents was "Which people would you ask for advice on how to choose a form of education?" With almost similar weights of $38 \%$ and $35 \%$ respectively, responses such as "knowns" and "friends" were chosen.
Other answers provided by survey participants were: "No one, I would choose what I want" - 26\%, "teachers" - $24 \%$ and "parents" - 21\%, and only $3 \%$ of the respondents chose not to answer this question (Figure 2). 


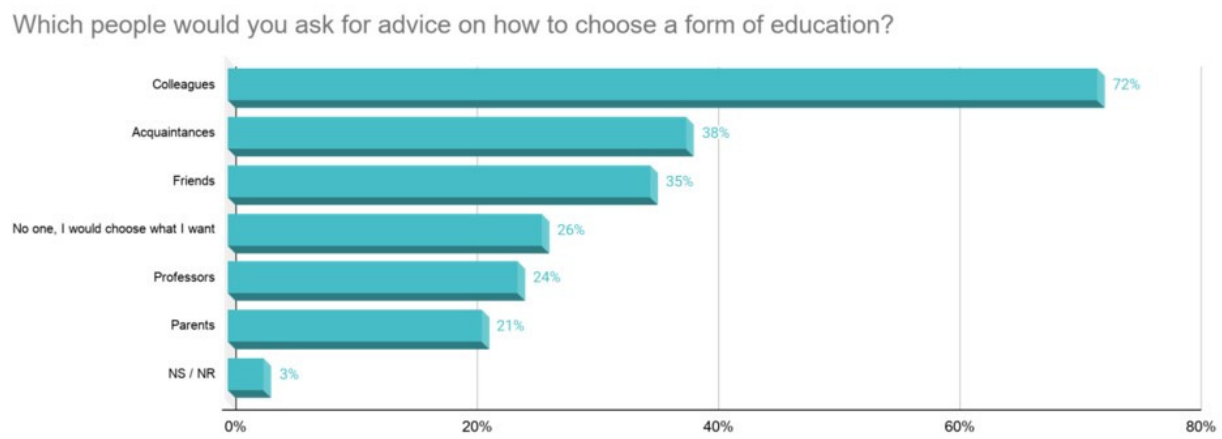

Figure 2

As can be seen from the images presented above, it is noted that there are several influencing factors in the choice of a university, each of which has its weight. However, none of these factors must be excluded.

\section{Factors that may influence students in choosing a university}

Considering the above, several factors can be drawn which may influence, to a greater or lesser extent, the choice of an educational establishment by a high-school student:

\section{Influence of colleagues}

Most of the time, colleagues are one of the most important factors that can influence the choice of a university by a high school student. Often, they tend to choose the same studies that their older colleagues have chosen.

\section{Influence of parents}

Another quite important factor in influencing the student's decision to choose a certain university is represented by parents. Most of the time, parents are thinking about the future that the child will have after completing his studies. They can also influence the field that the young man can join: technical, human, etc. The influence can also refer to the fact that, in some cases, parents can make the decision in place of the student regarding the chosen university. It is also parents who can direct their children to study abroad or in the country.

\section{Influence of teachers}

Teachers can be another factor of influence for high school students. The problem is in the studies that teachers in the school environment have taken up, which are often humanists, hence, the decision can only be influenced in one way.

\section{Influence of friends}

Sometimes, in the students' decisions, they weigh a lot the opinions of those close to them, as well as the information taken from the social media. It is natural for prospective students to listen to the views of others, but it is important that the decision is made individually by each person, because this decision will greatly influence his/her career.

\section{The prestige of the university}

The prestige of the university is a quite important factor by which a student's decision can be influenced when choosing the university, he wants to join. The academic, scientific, and professional prestige of a university should be an emblematic of higher education. Students pursue the outstanding professionalism of the teaching staff, the professional quality 
of many graduates; the recognition of that school as being included in the elite echelon of international academic education through international rankings.

\section{The opportunities after completion of studies}

The opportunities that universities offer to students, both during and after their studies, can be important when students choose the university they want to join. In this case, the examples can be numerous, ranging from the endowment of the university, the accommodation of the students and the employment opportunities after the completion of their studies, through the partnerships that the universities have with the representatives of the economic environment.

\section{The own persuasions}

The most important decisions are students' own decisions. Even if these decisions can have a certain impact on high school students, both positively and negatively, they also give them a certain sense of responsibility. The more indecisive a teenager is about choosing the field of study, the more tempted those around them are to intervene with suggestions. Most of the time, students are wondering if the decision taken is the right one. The answer is simple: When they choose correctly for themselves, they feel clarified, motivated, determined, and confident.

\section{The strategy of universities to attract students.}

So, for universities to attract as many students as possible, the solution proposed by this study is to develop a strategy in this regard, namely, a "Promotion Strategy among students":

- The university must present its educational offer, updated with new trends and connected to the increasingly technological future.

- The university must maintain a permanent link with the local, national, and even international press, through which it can communicate scientific achievements and research.

- The university must maintain a permanent connection with high school teachers, both by involving them in the various events organized by the university, and by constantly sending newsletters on the achievements of the university.

- Universities must ensure that students' parents know the opportunities that are offered to their graduates: scholarships, good conditions for courses, research opportunities, partnerships with businesses, as well as finding a stable and well-paid job after graduation.

- Most importantly, the university must get in touch with the student from the beginning of the preuniversity cycle by involving them in various events, sending them newsletters on the achievements of the university, and guiding them to professions they like, in line with what happens in everyday life: programming, robot development, medical device development, artificial intelligence, etc.

At the same time, universities should consider the prospects for the future of education. In a study conducted by the Competitiveness Initiative Company (INACO) in 2018, the following were stated: there are still over 750 million illiterates in the world $10 \%$ of the Earth's population does not know how to write, read, and calculate); only $6.7 \%$ of the population graduated from a university; the global learning market is huge $(\$ 107$ billion in 2016); $20 \%$ of the planet's workforce (mostly women) work in Education; the basic education of reading, writing and arithmetic are added to programming languages; the determination of the European Union to give free access to all scientific papers and patents is important; virtual reality becomes a school technology; Open University, from the famous Massachusetts Institute of Technology (MIT) offers 2300 
different Internet courses (STEM); great professors (like Abshok Goel of the Georgia Institute of Technology) use robots as assistants; education is personalized, a curriculum for each student; $60 \%$ of the children of the current generation will have professions and trades that do not yet exist; $60 \%$ of Earth's children also have a computer in the classroom where they study.

An agenda for the future of education was also proposed, presented in Figure 3:

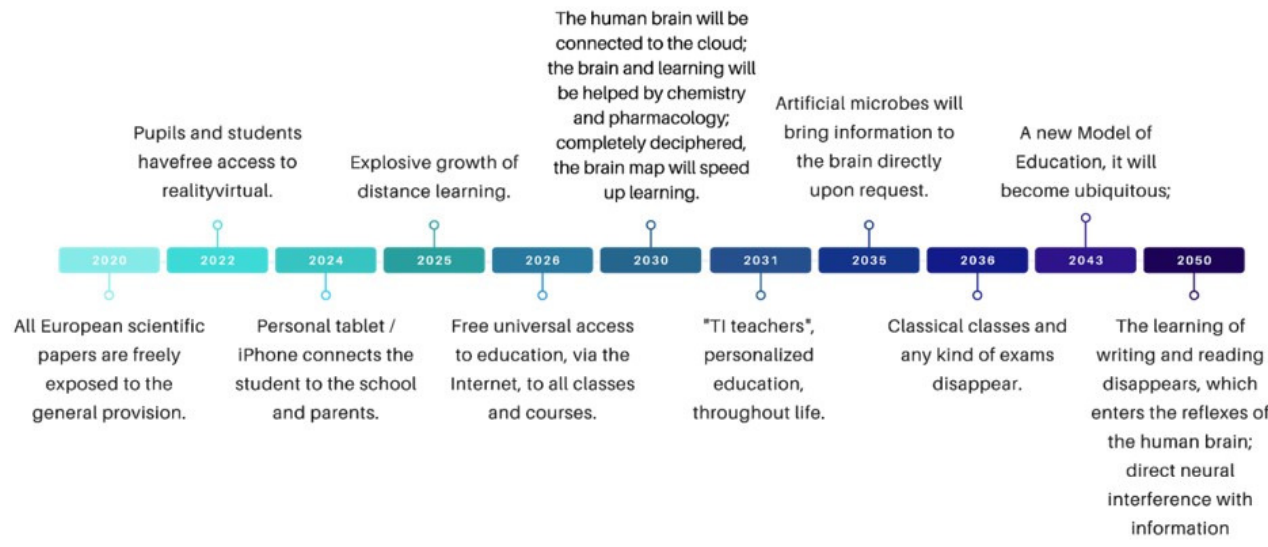

Figure 3: The agenda of the future in education

\section{Future Perspectives}

In the future, the authors of this paper aim to make a mathematical modelling to identify the share of influence of these factors on students' decisions in choosing the university. Basically, there will be a mathematical formula that will assign a percentage for each decision factor. Mathematical modelling will be useful to any university in implementing the "Strategy to promote the educational offer among students".

\section{Conclusions}

Based on the analyzed data in this paper, the rankings significantly help maintain and build the institutional position and reputation. The fact that a certain higher education institution has a ranking improves the chances of representing a potential choice by students.

At the same time, rankings - whether national or international - clearly have an impact on the public opinion, institutional decision-making, and individual choices.

Given the importance of higher education for the development of human capital, its cost for public funding and for individuals and their families, and the needs of businesses and industries; more and more young people are focusing on higher education, while universities pay greater attention to national and international rankings.

However, universities consider that a good positioning in these rankings not only implies a better visibility and a greater impact, but also allows the possibility to identify the institution's status and level of development compared to other universities around the world. Thus, universities choose to take a series of measures to promote themselves among students, as well as promoting the educational offer to the public, in general, in order to increase their prestige, visibility and attractiveness. In this sense, they 
diversify their specializations, make weekly newsletters, organize career fairs and internships, offer scholarships for exchange of experience, pay extra attention to foreign students, and focus on improving the prestige of the university.

Regarding the students, their decision is influenced by colleagues, parents, professors, friends, the prestige of the university, the opportunities after graduation and, finally, by their own beliefs.

Therefore, this study proposes the development of a strategy for universities to attract students, by promoting among them the educational offer, updated with new trends. However, universities should maintain a continuous contact with the press and high school teachers, both through involving them in various events, and communicating scientific achievements and research conducted. Finally, universities should ensure that students' parents know the opportunities offered to graduates (study scholarships, good conditions for courses, research opportunities, etc.). They should also keep close contact with students from the beginning of the pre-university cycle by getting them involved in various events, taking the perspectives of the educational future into account.

\section{Acknowledgments}

The article is financed by the University POLITEHNICA of Bucharest, through the project "Engineer in Europe" - an online system, registered at the Ministry of Education and Research under no. $457 / G P / 06.08 .2020$, by using the fund for financing special situations that cannot be integrated in the form of financing state higher education institutions.

\section{References}

- Mechno R. A., „Comparative analysis of international ranking systems for universities", IBIMA International Conference, Spain, 2020;

- Kehm B. M., „Global University Ranking - Impacts and Unintended Side Effects", European Journal of Education, vol 49, Germany, 2014;

- Robinson D., „The mismeasure of higher education? The corrosive effect of university ranking", Ethics in Science and Environment Politics, vol. 13, Germany, 2013;

- http://www.shanghairanking.com;

- http://nturanking.lis.ntu.edu.tw;

- https://www.timeshighereducatio n.com/;

- www.leidenranking.com;

- https://www.topuniversities.com/ university-rankings

- $\quad$ http://www.urapcenter.org/2018 /;

- https://www.scimagoir.com/;

- https://cwur.org/;

- https://www.usnews.com/educati on/best-global-universities;

- https://www.umultirank.org/;

- https://scholar.google.com/. 